\title{
Elaine Sherman: Marketing and Pioneer in Quality of Life Research
}

\author{
Elaine Sherman
}

Received: 28 February 2013 / Accepted: 2 June 2013 /

Published online: 25 June 2013

(C) Springer Science+Business Media Dordrecht and The International Society for Quality-of-Life Studies (ISQOLS) 2013

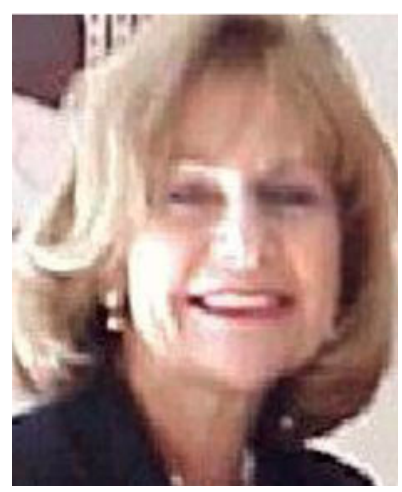

Contemplating my academic career, especially from my reflections of my "early years," reveals my strong research interests of blending the disciplines of marketing with quality of life issues.

This theme is evident in some of my academic research publications and my presentations to academic and practitioner conferences. More specifically, over the course of time, my interest in the "blending" of marketing and quality of life concerns has increasingly found a place in my published research and related conference presentations. They ranged over a variety of topics, including: the stereotypes of elderly women, health issues of the older populations, and the influence of happiness and life satisfaction of the elderly consumer segment.

More recently, some of my research interests have included the effects of new technologies, such as the internet and social media on quality of life. Another important research interest has included the changing political environment, with a variety of research on political trust and its effect on various voter segments. This

E. Sherman $(\bowtie)$

Department of Marketing and International Business, Hofstra University, Hempstead, NY, USA

e-mail: Ess1234@aol.com 
includes a recently published article in the 'Journal of Political Marketing, 2012 dealing with the topic of young voters' trust of information and media sources. Still other, recent research explored aspects the changing economic environment, including newer research on frugality and its effects on happiness and life satisfaction in a cross-cultural study contrasting American and China subjects in 2011.

In addition to my published and presented research findings, another important element of my "academic growth" was my professional involvement with the Academy of Marketing Sciences and the American Marketing Association. Specifically, within the context of the expanding visions of "societal marketing," there was an opportunity to further involve myself with dynamic social and public policy issues as they relate to the expansion of marketing thought and actions. This environment led to an opportunity to interact with a group of marketing scholars, who were also presented at these conference meetings. We all soon realized the need to have a new organization, one which would reflect our similar interests in quality of life issues, and its various other disciples, all dedicated to the growing concern for an expanded role of "quality of life." This in part led to the founding of ISQOLS, which has developed into a worldwide organization that reflecting a diverse group of those interested in "quality of life research." Furthermore, I have continued my interest in this topic by conducting for the past 24 years public opinion polls for a local television station with over 2 million viewers. I have also introduced many quality of life topics with my marketing students at Hofstra University where I have been teaching for 35 years as a fulltime professor of Marketing and International Business. Blending marketing and quality of life issues has influenced my academic life in the classroom in many of my over 100 presentations in more than 30 countries, and over 70 refereed academic articles.

\section{Selected Publications}

Sherman, E., Schiffman, L., \& Thelen, S. (2012). Young voters' trust of information and media sources: the 2008 U. S. Presidential Election. Journal of Political Marketing, 11(4), 246-265.

Sherman, E., Schiffman L., Zhang, Y. (2011). "A cross-cultural investigation of consumer frugality: the case of the United States and China" Fulfilling the worldwide sustainability challenge: strategies, innovations, and perspectives for forward momentum in Turbulent Times GBATA Global Business and Technology. Proceedings Istanbul, Turkey. (17):921-927

Schiffman, L., Thelen, S. T., \& Sherman, E. (2010). Interpersonal and political trust: modeling levels of citizens' trust. European Journal of Marketing, 44(3/4), 369-379. 